\title{
Penerapan Prinsip Akuntabilitas Dan Transparansi Dalam Pelayanan Pemerintahan di Kantor Pelayanan Terpadu Satu Pintu (PTSP) Kabupaten Sidenreng Rappang
}

\author{
Abdul Jabbar ${ }^{1}$ \\ Muhammad Arisal Asad ${ }^{2}$ \\ Muhammad Ikbal ${ }^{3}$ \\ Dosen Ilmu Pemerintahan Universitas Muhammadiyah Sidenreng Rappang, Indonesia ${ }^{1}$ \\ Dosen Administrasi Publik Universitas Muhammadiyah Sidenreng Rappang, Indonesia ${ }^{23}$ \\ ibr.nyonk1@gmail.com
}

\begin{abstract}
Keyword:
Effectiveness;

Perdasus;

$M R P$.

Abstract: The background that in the provision of government services the concept of good governance should be maximally applied, especially the principles of accountability and transparency. The purpose of this research;1) to analyze and describe the application of the principle of accountability in the services of Building Construction Permits (IMB), and 2) to analyze and describe the application of the principle of transparency in building Construction Permit (IMB) services in Sidenreng Rappang Regency. The research location is at the One-Stop Services Office (PTSP) of Sidenreng Rappang Regency. The research was conducted for three months, from September 2019 to March 2020. Data sources were obtained from interviews with bureaucratic officials and service users. Data collection techniques were through interviews, observation, documentation, and literature. Data analysis techniques are descriptive qualitative. The results of this study indicate that the Service Accountability of Building Permits (IMB) at the One-Stop Services Office (PTSP) of Sidenreng Rappang Regency is not fully accountable for services to service users based on inconsistent service references, service solutions where ease of service is still discriminatory, and priority to fulfill the interests of service users has not been fully concentrated in the interests of service users. The transparency of government services for Building Construction Permits (IMB) held by the OneStop Services Office (PTSP) of Sidenreng Rappang district can be illustrated that the quality of service is increasingly open and information related to Building Construction Permit (IMB) services to the community can run optimally. This is based on several indicators used, namely the openness and standardization of services that have been carried out by the bureaucracy, either directly or indirectly. The service process has also been implemented quickly, effectively, in accordance with the established Standard Operating Procedures (SOP). Regarding the transparency of service activity reporting, it has been implemented periodically and regularly. It's just that the actions of the bureaucratic apparatus still tend to be unfair and discriminatory.
\end{abstract}

Kata Kunci:

Good Governance;

Prinsip Akuntabilitas;

Prinsip Transparansi.
Abstrak: Latar Belakang bahwa dalampemberian pelayanan pemerintahan hendaknya konsep good governance diterapkan dengan maksimal, khususnya prinsip akuntabilitas dan transparansi. Penelitian ini bertujuan; 1) untuk menganalisis dan menggambarkan penerapan prinsip akuntabiltas dalam pelayanan Izin Mendirikan Bangunan(IMB), dan 2) untuk menganalisis dan menggambarkan penerapan prinsip transparansi dalam pelayanan Izin Mendirikan Bangunan(IMB) di Kabupaten Sidenreng Rappang. Lokasi penelitian di Kantor Pelayanan Terpadu Satu Pintu (PTSP) Kabupaten Sidenreng Rappang.Penelitian dilaksanakan selama tiga bulan yaitu mulai September 2019 
s.d Maret 2020.Sumber Data didapatkan dari hasil wawancara dengan aparat birokrasi dan masyarakat pengguna jasa.Teknik pengumpulan data melalui wawancara, observasi, dokumentasi dan kepustakaan.Teknik Analisis data yaitu deskriptif kualitatif. Hasil penelitian ini menunjukkan bahwa Akuntabilitas Pelayanan Izin Mendirikan Bangunan (IMB) pada Kantor Pelayanan Terpadu Satu Pintu (PTSP) Kabupaten Sidenreng Rappang belum sepenuhnya akuntabel dalam pelayanan kepada pengguna jasa berdasarkan acuan pelayanan yang tidak konsisten, solusi pelayanan dimana kemudahan pelayanan masih bersifat diskriminasi, dan prioritas pemenuhan kepentingan pengguna jasa belum dikonsentrasikan sepenuhnya untuk kepentingan pengguna jasa. Transparansi pelayanan pemerintahan Izin Mendirikan Bangunan (IMB) yang diselenggarakan oleh kantor Pelayanan Terpadu Satu Pintu (PTSP) kabupaten Sidenreng Rappang dapat digambarkan bahwa kualitas pelayanan sudah semakin terbuka dan informasi terkait pelayanan Izin Mendirikan Bangunan (IMB) kepada masyarkat dapat berjalan maksimal. Hal ini berdasarkan beberapa indikator yang digunakan yaitu keterbukaan dan standarisasi pelayanan yang sudah dilakukan oleh aparat birokrasi baik secara langsung maupun secara tidak langsung. Proses pelayanan juga telah diterapkan secara cepat, efektif, sesuai dengan Standar Operasional Prosedur (SOP) yang telah ditetapkan. Terkait mengenai transparansi pelaporan kegiatan pelayanan sudah diterapkan secara periodik dan teratur. Hanya saja, tindakan aparat birokrasi yang masih cendrung tidak adil dan diskriminatif.

\section{PENGANTAR}

Penyelenggaraan pelayanan publik yang dilaksanakan oleh aparatur pemerintah dalam berbagai sektor pelayanan, terutama yang menyangkut pemenuhan hak sipil dan kebutuhan dasar masyarakat, kinerjanya masih jauh dari yang diharapkan. Hal ini dapat dilihat antara lain dari banyaknya pengaduan dan keluhan dari masyarakat dan pelaku dunia usaha, baik melalui surat pembaca maupun media pengaduan lainnya, seperti menyangkut prosedur dan mekanisme kerja pelayanan yang berbelit-belit diakibatkan belum maksimalnya penerapan Standar Operasional Prosedur (SOP) dari suatu layanan, belum transparan, kurang informatif, kurang akomodatif, dan terbatasnya fasilitas, sarana, dan prasarana sehingga tidak menjamin kepastian (waktu, dan biaya).Kantor Pelayanan Terpadu Satu Pintu (PTSP) kabupaten Sidenreng Rappang merupakan salah satu pelaksana pelayanan publik yang bersinggungan langsung dengan masyarakat luas.Dalam pemberian pelayanan publik tersebut hendaknya konsep good governance juga diterapkan dengan maksimal, khususnya akuntabilitas dan transparansinya.Oleh karenanya diharapkan aparatur negara yang bekerja di dalamnya dapat memberikan pelayanan publik yang maksimal. Terlebih dalam hal akuntabilitas dan transparansinya..Kantor Pelayanan Terpadu Satu Pintu(PTSP) kabupaten Sidenreng Rappang juga mengalami hal yang tidak berbeda.Pembuatan Izin Mendirikan Bangunan (IMB) yang seyogyanya bisa berjalan lancar sesuai dengan Standar Operasional Prosedur (SOP) dan dapat diselesaikan dalam waktu yang singkat, cenderung kurang terlaksana dengan baik.

Akuntabilitas merujuk pada pengembangan rasa tanggungjawab publik bagi pembuat/ pengambil kebijakan/keputusan dipemerintahan, sektor privat, dan organisasi kemasyarakatan sebagaimana halnya kepada para pemilik (stakeholders).Khususnya dalam birokrasi pemerintahan, akuntabilitas merupakan upaya menciptakan sistem untuk memonitoring dan mengontrol kinerja birokrasi dalam kaitannya dengan kualitas, inefisiensi, dan perusakan sumberdaya, serta transparansi dalam manajemen kuangan, pengadaan, akunting dan penggunaan 
sumberdaya. Dari sudut kekuasaan, akuntabilitas menjamin adanya proses yang memenuhi syarat dalam pemilihan pejabat publik (pemegang kekuasaan) dan prosedur yang sehat dalam proses pengambilan keputusan/kebijakan strategis, adanya mekanisme evaluasi atas insentif yang diberikan kepada para pejabat publik atas kinerja pemerintah.

Menurut Dwiyanto etal (2002), untuk mengukur akuntabilitas penyelenggaraan pelayanan publik dalam penelitian dilihat melalui indikator-indikator kinerja yang meliputi:

Pertama,Acuan pelayanan yang dipergunakan aparat birokrasi dalam proses penyelenggaraan pelayanan publik. Indikator tersebut mencerminkan prinsip orientasi pelayanan yang dikembangkan oleh birokrasi terhadap masyarakat pengguna jasa. Kedua,Tindakan yang dilakukan oleh aparat birokrasi apabila terdapat masyarakat pengguna jasa yang tidak memenuhi persyaratan yang telah ditentukan; dan Ketiga,Dalam menjalankan tugas pelayanan, seberapa jauh kepentingan pengguna jasa memperoleh prioritas dari aparat birokrasi.

Transparansi adalah prinsip yang menjamin akses atau kebebasan bagi setiap orang untuk memperoleh informasi tentang penyelenggaraan pemerintahan, yakni informasi tentang kebijakan, proses pembuatan dan pelaksanaannya, serta hasil-hasil yang dicapai. Transparansi yakni adanya kebijakan terbuka bagi pengawasan.Sedangkan yang dimaksud dengan informasi adalah informasi mengenai setiap aspek kebijakan pemerintah yang dapat dijangkau oleh publik. Keterbukaan informasi diharapkan akan menghasilkan persaingan politik yang sehat, toleran, dan kebijakan dibuat berdasarkan pada preferensi publik.

Menurut Sutedi (2009) secara ringkas dapat disebutkan bahwa, prinsip transparasi paling tidak dapat diukur melalui sejumlah indikator seperti, Pertama, Mekanisme yang menjamin sistem keterbukaan dan standarisasi dari semua prosesproses pelayanan publik. Kedua,Mekanisme yang memfasilitasi pertanyaan-pertanyaan publik tentang berbagai kebijakan dan pelayanan publik, maupun proses-proses didalam sektor publik. Ketiga,Mekanisme yang memfasilitasi pelaporan maupun penyebaran informasi maupun penyimpangan tindakan aparat publik didalam kegiatan melayani.

Pada dasarnya setiap manusia membutuhkan pelayanan, bahkan secara ekstrim dapat dikatakan bahwa pelayanan tidak dapat dipisahkan dengan kehidupan manusia (Sinambela, 2010:3).

Tugas utama dari setiap instansi pemerintahan adalah memberikan pelayanan atau menyelenggarakan pelayanan publik (public service) agar terwujud kesejahteraan bagi rakyat (public welfare). Menurut Tampubolon pelayanan berarti, "Orang yang melakukan sesuatu yang baik bagi orang lain.karena itu, seorang pelayan yang baik ialah "melayani, bukan dilayani".

\section{METODE PENELITIAN}

Jenis Penelitianini akan menggunakan metode kualitatif. Penelitian dilaksanakan di Kantor Pelayanan Terpadu Satu Pintu (PTSP)Kabupaten Sidenreng Rappang Provinsi Sulawesi Selatan, dengan harapan bahwa lokasi penelitian tersebut,penulis dapat menangkap keadaan yang sebenarnya dari objek yang diteliti.Untuk memperoleh datadata yang dibutuhkan sesuai dengan permasalahan yang diteliti, maka penulis melakukan tehnik pengumpulan data, diantaranya wawancara, observasi atau 
pengamatan,dokumentasi,kepustakaan. Teknik analisis data dalam penelitian ini yaitu deskriptif.

\section{HASIL DAN DISKUSI}

Hasil penelitian menunjukkan bahwa penerapan prinsip-prinsip good governance dalam birokrasi pelayanan pemerintahan belum berjalan optimal, dilihat dari prinsip akuntabilitas yang belum sepenuhnya akuntabel dalam pelayanan kepada pengguna jasa berdasarkan acuan pelayanan yang belum terintegrasi sampai kepada pembuatan peraturan daerah, solusi pelayanan dimana kemudahan pelayanan masih bersifat diskriminatif, dan prioritas pemenuhan kepentingan pengguna jasa belum dikonsentrasikan sepenuhnya untuk kepentingan pengguna jasa.

Ditinjau dari prinsip transparansi berdasarkan keterbukaan dan standarisasi pelayanan petugas sudah memberikan informasi baik secara langsung maupun tidak langsung kepada pengguna jasa, kejelasan terkait prosedur pelayanan sudah sesuai dengan Standar Operasional Prosedur (SOP) mekanisme pelayanan, dan pelaporan sudah dilakukan secara rinci dan periodik, hanya saja tindakan aparat birokrasi kadangkala tidak adil dan mengutamakan orang yang dikenal atau yang memiliki jabatan dalam struktural birokrasi.

Dalam Penerapan Prinsip Akuntabilitas dapat dilihat dari berbagai aspek, diantaranya : Pertama, Acuan Pelayanan berdasarkan temuan di lokasi menunjukkan bahwa acuan pelayanan pada Kantor Kantor Pelayanan Terpadu Satu Pintu Kabupaten Sidenreng Rappang adalah berbagai aturan dan ketentuan formal yang ditetapkan oleh pemerintah sebagaimana hasil wawancara Kepala Kantor Kantor Pelayanan Terpadu Satu Pintu Kabupaten Sidenreng Rappang :

"Kantor PTSP Kabupaten Sidrap melayani berbagai macam jenis perizinan dan masing-masing perizinan tersebut sudah diatur melalui Standar Operasional Kantor PTSP yang didalamnya telah diatur dasar hukum masing-masing jenis perizinan.Secara umum kami mengacu pada Peraturan Bupati Sidenreng Rappang No. 24 Tahun 2012 tentang pendelegasian kewenangan perizinan kepada Kantor PTSP Kabupaten Sidrap."(Kepala Kantor PTSP Kabupaten Sidrap, 18 November2019)

Pada prinsipnya acuan pelayanan dalam standar operasional kantor PTSP Kabupaten Sidrap telah mangatur standar pelayanan sebagaimana dalam UndangUndang No. 25 Tahun 2009 tentang pelayanan publik, sekurang-kurangnya meliputi : persyaratan prosedur pelayanan, waktu pelayanan, biaya pelayanan, sarana dan prasarana, kompetensi petugas.

Berdasarkan hasil wawancara beberapa narasumber, penulis tidak menemukan adanya biaya yang harus dikeluarkan untuk pengambilan formulir perizinan pada Kantor Pelayanan Terpadu Satu Pintu( PTSP) Kabupaten Sidrap.

“....Tidak ada biaya untuk ambil formulir, kalau datang kesini cukup bilang saja izin yang mau diurus, petugas akan memberikan formulirnya sama kita."(pengguna jasa,19 November2019)

“....Saya sudah sering mengurus dikantor ini, biaya untuk formulir memang gratis, tinggal diambil saja baru dilengkapi berkasnya."(pengguna jasa,19 Januari2020).

“....Tidak ada biaya untuk formulir, dari dulu memang sudah begitu, yang saya bayar biasanya hanya biaya retribusi saja...."(pengguna jasa, 20 November 2019).

Hal tersebut diperjelas melalui penuturan Kasi.Pelayanan Kantor Pelayanan Terpadu Satu Pintu( PTSP) Kabupaten Sidrap. 
“.....Untuk pengambilan formulir diberikan secara cuma-cuma, kami tidak pernah membebani pengguna jasa dengan biaya formulir, petugas kami juga telah membubuhi stempel gratis pada blangko formulir..."(Kasi. Pelayanan, 20November2019).

Kedua, Solusi Pelayanan, Berdasarkan temuan dilokasi penelitian, solusi yang ditawarkan oleh petugas ketika pengguna jasa mengalami kesulitan dalam pelayanan adalah dengan memberikan informasi yang dibutuhkan. Berikut penuturan aparat birokrasi :

"Pengguna jasa kadang kala mengalami kesulitan dalam pelayanan, misalnya berkas tidak lengkap dan kami berusaha memberikan informasi yang dibutuhkan pengguna jasa sesuai dengan izin yang diurus"(Kasi.Pemprosesan.8 Februari2020).

Pernyataan diatas dibenarkan oleh beberapa pengguna jasa yang mengalami kesulitan dalam melengkapi persyaratan pelayanan, berikut penuturan pengguna jasa :

" Saya mau IMB, tapi persyaratannya sudah saya penuhi kecuali gambarnya, jadi petugas memberi tahu saya mengenai persyaratan yang kurang agar permohonan saya diterima....."(Pengguna Jasa. 6 Februari2020).

“....Saya baru kemarin mengambil formulir untuk mengurus Surat Izin Tempat Usaha (SITU), setelah lengkap saya datang lagi untuk mengembalikan formulir beserta persyaratannya sayangnya berkas saya belum lengkap, petugas telah menjelaskan berkas-berkas yang mesti saya lengkapi....."(Pengguna Jasa. 27 Januari2020).

Persyaratan pelayanan yang seringkali tidak dipenuhi pengguna jasa sehingga pengguna jasa tidak mendapatkan tindak lanjut terhadap pelayanan, namun demikian petugas lebih memilih untuk mengarahkan pengguna jasa untuk melengkapi persyaratan yang belum dilengkapi.Hal ini menunjukkan solusi pelayanan yang diberikan petugas masih berkiblat pada aturan yang telah ditetapkan.

Berdasarkan hasil observasi, penulis juga menemukan solusi yang diberikan petugas akan lebih mudah jika pengguna jasa mempunyai kenalan dengan petugas. Berikut penuturannya pengguna jasa :

“....Berkas saya sebelumnya ditolak tapi sudah diterima, untung ada teman disini jadi semuanya bisa di atasi....."(Pengguna Jasa. 2 Februari2020)

Ketiga, Prioritas Kepentingan Pengguna Jasa Dalam Pelayanan , Berdasarkan hasil wawancara dengan Kepala Seksi PelayananKantor Pelayanan Terpadu Satu Pintu kabupaten Sidenreng Rappang mengatakan bahwa :

"Sumber daya yang kami punya sangat terbatas, pegawai tetap hanya 13 orang, ditambah pegawai honorer 15 orang. Tapi kami selalu berusaha bekerjasama dengan baik, pegawai honorer juga kami libatkan dalam pelayanan, sebagian menjadi operator dan sebagian lagi sebagai pelaksana loket"(Kasubag.Tata Usaha Kantor PTSP Kabupaten Sidrap, 18 Januari2020).

Berdasarkan hasil observasi penulis, terkadang petugas tidak ada ditempat karena sedang mengurus kegiatan di dalam maupun di luar kantor yang dapat merugikan pengguna jasa. Dengan adanya pemberian kegiatan diluar tugas pokok pelayanan, aparat birokrasi menjadi cenderung mengabaikan kepentingan pengguna jasa, namun.Hal inilah yang membuat pengguna jasa harus menunggu. Padahal idealnya petugas harus berada di kantor pada pukul 07.45 WITA hingga pukul 16.00 WITA, namun lagi-lagi dalam realisasinya hal tersebut tidaklah sejalan dengan aturan. 
"Saya datang jam 8.30 pagi, tetapi petugas belum ada diloket. katanya petugas yang bersangkutan belum datang, sehingga saya memilih untuk pulang dari pada menunggu"(Pengguna Jasa. 20 Januari2020).

"Saya mau mengambil izin, saya datang jam 2 petugas sudah tidak ada diloket tadi saya bertanya sama pegawai yang lain, katanya pegawai sudah pulang"(Pengguna Jasa. 11 Februari2020).

Pernyataan diatas menunjukkan bahwa kedisiplinan petugas belum sepenuhnya diterapkan, dari hasil observasi penulis menemukan ketiadaan Kepala Kantor selama 4 (Empat) hari untuk melaksanakan tugas kedinasan di luar kota sementara kewenangan penandatangan perizinan didelegasikan kepada Kepala Kantor Pelayanan Terpadu Satu Pintu( PTSP) Kabupaten Sidrap untuk mempercepat proses pelayanan.

"Pimpinan kadang keluar kota untuk dinas, tapi pelayanan tetap berlangsung, jadi saya rasa hal itu tidak jadi permasalahan"(Sub. Bag.Tata Usaha Kantor PTSP Kabupaten Sidrap, 18 Januari2020).

Namun, disisi lain masyarakat pengguna jasa berpendapat bahwa pemenuhan kepentingan pengguna jasa setidaknya telah mengalami peningkatan di bandingkan tahun-tahun sebelumnya, apalagi pengurusan satu pintu yang diterapkan pemerintah membuat masyarakat menaruh harapan untuk mewujudkan harapan masyarakat dalam penyelenggaraan pelayanan.

“Keberadaan kantor PTSP diharapkan mampu melayani masyarakat dengan baik, saya rasa masyarakat pada umumnya juga mengharapkan hal yang demikian, kalau dulu kita harus bolak balik ke mengurus, sekarang tinggal satu tempatnya"(Pengguna Jasa. 1 Februari2020).

Dalam Penerapan Prinsip Transparansi dapat dilihat dari berbagai aspek, diantaranya : Pertama,Keterbukaan dan Standarisasi Pelayanan,Berdasarkan hasil wawancara Kepala Bidang Pengolahan Data dan Pemeriksaan Kantor Pelayan Terpadu Satu Pintu Kabupaten Sidenreng Rappang.

“ Bentuk-bentuktransparansi yang kami berikan dalam pelayanan publik adalah denganmemberikan informasi kepada masyarakat mengenai jenis pelayanan yang kamibuat dalam selayang pandang Kantor Pelayan Terpadu Satu Pintu Kabupaten Sidenreng Rappang, dimana didalamnyaterdapat persyaratan, biaya, waktu penyelesaian dan system pengurusanya, jaditidak ada yang kami tutup-tutupi dalam memberikan pelayanan kepada publik. Selain itu kami juga membuat papan prosedur pelayanan dan baliho terkait mekanisme pelayanan IMB bahkan kantor kami telah meluncurkan pelayanan Berbasis ISO 9001:2015 dinamakan Si-IDA. Jadi masyarakat bisa cek segala sesuatunya tentang PTSP melalui Web siidaperizinan.sidrapkab.go.id/". (Kepala Bidang Pengolahan Data dan Pemeriksaan, 13 Februari2020).

Lebih lanjut Kepala Bidang Pengolahan Data dan Pemeriksaan Kantor Pelayan Terpadu Satu Pintu Kabupaten Sidenreng Rappang mengatakah bahwa :

" Bahwa mengenai informasi yang disampaikan kepada masyarakat tentang Pengurusan Izin Mendirikan Bangunansecara langsung disosialisasikan olehPegawai Kantor Pelayan Terpadu Satu Pintu kepada masyarakat, informasi tentang tata cara pengurusan Izin Mendirikan Bangunani (IMB) ini bisa didapat di Kantor Pelayan Terpadu Satu Pintu ini, bahkan di Web si- 
idaperizinan.sidrapkab.go.id/ telah kami uraikan secara terperinci. Apabila masyarakat membutuhkan informasi maka dengan tangan terbuka kami siap membantu "(Wawancara, 13 Februari2020).

Dari Pernyataan diatas dapat kita simpulkan bahwa keterbukaan informasi dan strandarisasi pelaksanaan pelayanan IMB di Kantor Pelayanan Terpadu Satu Pintu ( PTSP ) kabupaten Sidenreng Rappang telah berjalan maksimal.

Kedua,Proses Pelayanan, Berdasarkan hasil wawancara Kepala Seksi Pelayanan Kantor Pelayan Terpadu Satu Pintu Kabupaten Sidenreng Rappang.

“ Untuk proses penyelesaian IMB itu membutuhkan waktu 3 sampai 7 hari, karena ada beberapa persayaratan penerbitan IMB itu yang harus dipenuhi. Tapi kalau semuanya berkasnya lengkap, bisa kita urus juga dengan cepat " (Kepala Seksi Pelayanan, 9Februari2020).

Dari hasil observasi, penulis menemukan petugas membantu pengguna jasa dalam mengatasi kesulitan dalam pelayanan meskipun harus menunggu lama, berikut hasil wawancara dengan narasumber terhadap kesulitan yang dialami pengguna jasa:

“....Saya mengurus Izin Mendirikan Bangunan (IMB) tetangga saya, saya harus mengeluarkan uang di kelurahan sebanyak Rp. 70.000,- dan di Kecamatan sebanyak Rp. 50.000,-, sayangnya berkasnya ditolak karena keterangan gambar bangunannya tidak sesuai, petugaspun memberi contohnya dan membantu saya menyelesaikan berkas saya meskipun harus tertunda sampe 3 hari baru diterima kembali oleh petugas....."(Pengguna Jasa. 2 Februari2020).

Dari pernyataan pengguna jasa, hal tersebut membuktikan adanya pelayanan yang cepat dan efektif yang dilakukan oleh petugas pelayanan IMB. Hal ini menunjukkan adanya tindakan yang mengutamakan pelayanan pengguna jasa sehingga kebutuhannya bisa terpenuhi. Namun, penggunan jasa tetap harus melalui mekanisme dan prosedur yang telah diatur dalam pelayanan IMB.

Pelayanan dengan cepat dan tepat sesuai dengan waktu yang telah ditentukan, maka hal tersebut sudah sesuai denagn SOP terkait prosedur/tata cara pengurusan IMB. Sehingga petugas harus memiliki keahlian dala mengoperasikan perangkat-perangkat pelayanan IMB sehingga proses pelayanan bisa berjalan sesuai dengan prosedur yang ada.

"Kami sudah melaksanakan tugas dalam proses pengurusan IMB sesuai dengan prosedur yang telah ditentukan. Apabila persyaratan dan dokumen dari pemohon sudah lengkap, tentu kami bisa memberikan pelayanan dengan cepat". (Kasi. Pelayanan, 9Februari2020).

Berbeda dengan pendapat pengguna jasa yang telah disampaikan dalam proses wawancara, yaitu :

"Walaupun saya tidak masalah harus lama menunggu dalam proses penerbitan IMB, namun menurut saya petugas itu sedikit lambat. Seharusnya bisa cepat jadi.Karena persyaratannya sudah lengkap" (Pengguna Jasa, 13Februari2020).

Ketiga,Pelaporan Pelayanan dan Tindakan Aparat Publik Dalam Kegiatan Melayani,Berdasarkan hasil wawancara dengan Kepala Sub Bagian Tata UsahaKantor Pelayanan Terpadu Satu Pintutentang prinsip-prinsip dalam pelaporan pelaksanaan pengawasan terhadap proses pelayanan publik, yang mengatakan bahwa:

“ Berdasarkan pada peraturan perundang-undangan yang berlaku tentang pelaksanaan pengawasan terhadap kegiatan atau pekerjaan pada suatu organisasi dalam hal ini instansi pemerintah Kantor Pelayanan Terpadu Satu Pintu (PTSP), maka konsisten dan proporsional pengawasan dalam bentuk pelaporan harus 
dibuat secara sistematis dan berdasarkan pada data yang actual, akurat dan factual. Khususnya dalam menyusun laporan pelaksanaan pengawasan. Diharapkan dapat melakukan koordinasi dengan pejabat struktural dalam lingkup internal organisasi baik secara vertikal, horizontal dan lintas saluran untuk menciptakan efektivitas dan efisien pelaksanaan pekerjaan ". (wawancara, 18 Februari2020).

Tindakan penyelenggaraan pelayanan publik dapat dilihat dari sejauh mana hakhak konsumen mendapatkan pelayanan yang transparan, efisien dan adanya jaminan kepastian pelayanan dihargai oleh aparat birokrasi dalam memberikan pelayanan kepada masyarakat.

Berdasarkan observasi di lokasi penelitian, kesopanan dan keramahan petugas yang diwujudkan dalam sapaan tertentu masih belum bisa diterapkan oleh aparat dalam menjalankan tugas pelayanan. Berikut tanggapan masyarakat pengguna jasa mengenai sapaan dan sikap petugas :

"Saya tahu kondisi pelayanan disini, saya datang dari tadi tapi petugas masih juga asyik, senyum-senyum sendiri memainkan HP nya di tangan ".(Pengguna Jasa, 11 Februari2020).

Indikator lain untuk mengukur perilaku etis aparat dalam pelayanan publik yaitu tindakan diskriminatif petugas dalam memberikan pelayanan, dalam realitas pelayanan publik yang diselenggarakan ternyata masih ada petugas yang melakukan tindakan diskriminatif, hal ini tercermin dari penuturan responden berikut ini :

"Saya sudah menunggu sekitar 30 Menit, tapi belum juga dipanggil. Tidak lama kemudian datang bapak yang pakai baju dinas dengan segera petugas langsung melayani ". (Pengguna Jasa, 11 Februari2020).

Lebih lanjut pengguna jasa yang lain berpendapat bahwa :

" IMBsaya belum juga terbit jadi saya minta tolong sama salah satu anggota DPRD dari dapil saya biar cepat diproses, ini sementara saya tunggu mudah-mudahan selesai hari ini" (Pengguna Jasa, 11 Februari2020).

Tindakan diskriminasi yang dilakukan petugas membuat pengguna jasa enggan mengurus IMB, pengguna jasa lebih memilih untuk menitipkan berkasnya kepada orang-orang tertentu yang dianggap lebih dihormati oleh petugas, hal ini merupakan wujud keputus asaan masyarakat untuk berurusan dengan birokrasi.Padahal penyelenggaraan pelayanan publik yang beretika adalah pelayanan yang memperlakukan setiap pengguna jasa secara wajar tanpa harus melihat latar belakang status, pekerjaan, pendidikan, suku, agama dan ras.

\section{KESIMPULAN}

Kesimpulan yaitu penerapan prinsip Akuntabilitas aparat birokrasi dalam hal pelayanan IMB harus dikedepankan sesuai dengan SOP yang ada. Dalam memberikan solusi pelayanan harus mengedepankan sikap tanpa memandang status dan kedudukan. Sehingga masyarakat bisa mendapatkan prioritas dalam pelayanan prima oleh aparat birokasi.

Hal ini berdasarkan beberapa indikator yang digunakan yaitu acuan pelayanan yang tidak konsisten, terutama waktu penyelesaian berkas yang selalu mendominasi keluhan masyarakat; Solusi pelayanan yang belum sepenuhnya memberikan kemudahan kepada pengguna jasa, kemudahan masih bersifat diskriminasi; Prioritas 
kepentingan pengguna jasa yang belum sepenuhnya dikonsentrasikan untuk kepentingan pengguna jasa.

Transparansi internal harus terbangun. Terutama terhadap etika aparat/ petugas pelayanan, misalnya dengan memberikan penghargaan kepada petugas yang memberikan pelayanan yang terbaik serta sanksi kepada petugas yang terbukti merugikan pengguna jasa dalam penyelenggaraan pelayanan. Selain itu, tindakan aparat birokrasi pelayan pemerintahan harus mengedepankan azas kesamaan hak tanpa tebang pilih dalam memberikan pelayanan kepada pengguna jasa.

Hal ini berdasarkan beberapa indikator yang digunakan yaitu keterbukaan dan standarisasi pelayanan yang sudah dilakukan oleh aparat birokrasi baik secara langsung maupun tidak langsung. Proses Pelayanan yang telah berupaya memberikan pelayanan secara cepat, efektif dan sesuai dengan SOP yang ada. Dan terkait mengenai transparansi pelaporan kegiatan pelayananan sudah diterapkan secara periodik dan teratur. Hanya saja tindakan aparat birokrasi yang masih cendrung tidak adil dan diskriminatif.

\section{REFERENSI}

Dwipayana, AAGN. Ari.2003. Membangun Good Governance. RajaGrafindo Pustaka, akarta Grana, Judistira K. 2009.

Dwiyanto, A. Partini, Ratminto, B. Tamtian, W. Kusumasari, B. Nuh, M. 2002. Reformasi Birokrasi Publik di Indonesia. Pusat Studi Kependudukan dan Kebijakan UGM, Yogyakarta.

Garini. India. 2011. Transparansi dan Akuntabilitas berpengaruh terhadap Kinerja Instansi Pemerintah di Kota Bandung secara Parsial dan Simultan. Skripsi.Universitas Komputer Indonesia Bandung.

Harbani, Metodologi Penelitian Kualitatif. Bandung: Penerbit Remaja Rosdakarya.

Pulukadang, Mahmudi. 2010. Manajemen Kinerja Sektor Publik. Edisi Kedua. UPP STIM YKPN. Yogyakarta.

Moenir, H.A.S., 2010, Manajemen Pelayanan Umum di Indonesia, Bumi Aksara, Jakarta.

Pandji Santosa. 2008. Administrasi Publik. Teori dan Aplikasi Good Governance. Refika Aditama. Bandung

Sedarmayanti. 2004. Good Governance Kepemerintahan Yang Baik. Bagian Kedua. Mandar Maju. Bandung.

Sinambela, L.P.2010. Reformasi Pelayanan Publik. Teori, Kebijakan dan.Implementasi. cetakan kelima Bumi Aksara. Jakarta.

Sugiono 2010. Metode Penelitian Kuantitatif Kualitatif. Alfabeta. Bandung.

Sutedi, 2009. Implikasi Hukum atas Sumber Pembiayaan Daerah Dalam Karangka Otonomi Daerah.Sinar Grafika Jakarta.

Yeremias T. Keban, 2011, Memahami Good Governance dalam Perspektif Sumber Daya Manusia.Cetakan pertama. Gava Media. Yogyakarta. 